\title{
Customer Experience: Are We Measuring the Right Things?
}

\author{
Authors: \\ Prof. Dr. Philipp "Phil" Klaus \\ Professor of Customer Experience and Marketing Strategy \\ ESCEM School of Business and Marketing \\ E-mail:dr.philipp.klaus@gmail.com
}

Dr Philipp "Phil" Klaus is Professor of Customer Experience and Marketing Strategy at ESCEM School of Business and Management, France, Visiting Fellow at Cranfield University School of Management and holds visiting professorships at LUMSA University in Rome, Italy and the University of Valencia in Spain. His areas of expertise include customer experience strategy and management, customer experience quality, marketing strategy, the influence of marketing activities and customer experience on consumer behaviour and the financial performance of organizations. Phil is a frequent keynote speaker at public and in-company seminars and conferences around the world. He is an experienced senior marketing manager and management consultant with an active, international portfolio of Blue Chip clients from the financial services, retail, luxury goods and the energy sectors, for whom he advises on customer experience strategy, profit enhancement, customer behaviour, best practice and business development.

Dr Stan Maklan is Senior Lecturer in Strategic Marketing at the Cranfield University School of Management: s.maklan@cranfield.ac.uk.Prior to joining academe, Stan had 20 years' senior, international experience with blue chip organizations in consumer marketing, marketing services and IT-Management consulting. Stan established the UK CRM practice for a world leader in IT services. His research interests are dynamic capability development, CRM, customer experience, organizational brand development and marketing accountability.

Citation:

Maklan, S. and Klaus, Ph. (2011), "Customer Experience: Are We Measuring the Right Things," International Journal of Market Research, Vol. 53, No. 6, pp. 771-92.

Link to publisher website:

http://www.warc.com/Pages/Search/WordSearch.aspx?q=AID:95785\&Filter=ALL\%2 0OF\%20WARC\&Area=ALL\%20OF\%20WARC 


\section{Abstract}

Marketing theory and practice evolved dramatically through a series of transformations from products, to services and, recently, customer experiences. Each stage has its own perspective on marketing's purpose, the nature of customer value and measurements that calibrate performance and guide managerial decisions. The latter is of particular interest to market researchers. Measurement (research) typically lags changes in marketing theory due to institutional factors and the time for new practices to diffuse. The authors posit that firms still measure customer experience against criteria more suited for evaluating product and service marketing. Research practice seems rooted to 1990s notions of service quality, itself an outgrowth of Total Quality Management originating in manufacturing during the 1980s. The authors argue that market researchers will serve their organisations and customers better if they take an active role updating the customer experience measurement commensurate with advances in the conceptualisation of that which firms offer customers.

\section{A Rapid Evolution from Product to Service to Experience}

Marketing practice and research have undergone a series of large-scale transformations over the past 25 years, shifting focus from (1) creating product brands to (2) building customer relationships through service marketing and now to (3) creating compelling customer experiences. The authors propose that marketing research has not kept up with these changes (Gordon 2006), generating a mismatch between what marketers are now trying to achieve and what market research measures.

The first marketing "paradigm shift", the change from product brand to service-based relationship marketing, was acknowledged in the 1990s. Its proponents accurately described a change in both customer behaviour and organisational strategies that emphasised the value of the customer-company relationship in addition to the intrinsic utility of the goods and services offered (Gronroos 1994; Christopher 1996; Sheth et al. 2000; Payne \& Frow 2005). Product marketing was not "dead"; it was still necessary, but no longer sufficient to remain competitive. No sooner had the marketing community edged towards agreement on this major transformation, than the growth of the Internet spurred for a second change. The Internet is transforming relationship marketing from its initial database orientation (Peppers \& Rogers 1994; Payne \& Frow 2005), into collaborative relationships with customers. In an important article identifying types of marketing practices, Coviello et al. (2002) distinguish database marketing from interactive customer relationships, the second being described as the more evolved marketing practice. This emerging connected world is not only more interactive, it is community-centric rather than company-centric (Achrol \& Kotler 1999) and supported by the increasingly "rich data" (Hoffman \& Novak 1996) on the Internet (e.g. Skype video, You Tube). These new forms of customer communication allow firms to compete both in the market for physical goods and to create markets for value-added management of information flows around those 
goods (Rayport \& Sviokla 1994; Weiber \& Kollman 1998). Many scholars go so far as to suggest that marketers should conceive all goods as services (Vargo \& Lusch 2004) and that the basis of offers must be thought of as product-service systems, that is, systems that provide the experience (value) customers want without necessarily requiring them to own the products that create the experience. The dominance of the service economy in Western economies is now an article of faith, widely cited in both academic and practitioner marketing journals.

This rapid evolution of marketing theory and practice is now continuing to a postservice marketing phase. Vargo and Lusch (2004) propose that marketing has evolved from bringing goods "to market" through a stage of market and consumer targeting ("marketing to") and is now focused on "market with": co-creating value collaboratively with customers over an extended time frame. Co-creation unites the focal company's network of relationships with customers' capabilities, enabling customers to achieve higher-order goals or objectives. These higher-order goals are termed value-in-use which is defined as "a customer's functional outcome, purpose or objective that is directly served through the product/service consumption" (Macdonald et al. 2009, p.3). Other researchers describe a similar development of marketing from transaction, to relation and ultimately to networks wherein the focal firm's capabilities and assets facilitate customers creating value directly with other participants in a networked environment (Maklan \& Knox 2009; Coviello et al. 2002). Whilst each perspective of the evolution of marketing has its own conceptualisation and terminology, they offer, to a great extent, parallel and commensurate perspectives on the changing focus of marketing practice and the value of the firm's offer.

The authors assert that this rapid evolution of marketing "paradigms" mirrors a real world occurrence of marketplace competition moving from products, to services to a post-product, post-service phenomenon that is still evolving and not yet fully formed. However, we argue that the most popular expression of this emerging marketplace reality is customer experience (Lemke et al. 2010; Gambetti \& Graffigna 2010; Klaus \& Maklan 2007).

The term experience economy possibly originates with Pine and Gilmore (Gilmore \& Pine II 1997; Gilmore \& Pine II 2002) who make the overt claim that experience represents a move beyond products and service. Their work, echoed by many at that time, focused the discussion of experience upon immersive environments such as Starbucks, American Girl Dolls (2004), Harley Davidson outings (Schouten \& McAlexander 1995) or white river rafting (Arnould \& Price 1993). Nonetheless, this encouraged researchers to rediscover much earlier scholarship arguing that people buy goods and services as a means to fulfil deeper emotional, sensory and hedonic aspirations. With this lens, what matters to customers is how they experience the extended process of acquiring, integrating and deploying that which is necessary for them to achieve their aspirations and higher order goal, that is, value-in-use. Vargo and Lusch (2004) contrast this with traditional Goods Dominant Logic that sees value arising from economic exchange, that is, value is measured by the price paid (price premium to competitors). Whilst scholars and practitioners acknowledge that experience should be the new focus of managerial attention, they are less unified on both its precise definition and its measure. 
This creates a dilemma for market researchers. Whilst acknowledging that organisations are increasingly competing on the basis of customer experience, the concept is defined imprecisely and, as yet, there are no widely agreed measures of it. The authors maintain that market research remains wedded to a product / service era inspired mantra of quality whose limited conceptualisation of experience does not help organisations assess how customers evaluate their organisations' offers.

In this article, we focus on one of the most profound changes to measuring marketing effectiveness relevant to the emerging experience marketing model. The paper is structured as follows: first we discuss service quality, that which most firms measure today, and we assert that its conceptualisation is too limited to capture that which firms wish to achieve - better customer experience. In so doing, we review briefly the most widely researched and used measure of service quality, SERVQUAL. We then suggest how market researchers can extend the notion of quality to measure customer experience. We illustrate this in practice with an example of an empirically validated measure of experience quality for a UK mortgage provider. Finally we discuss the implications of measuring experience quality on the role of market researchers.

\section{From Measuring Service Quality to Customer Experience}

The authors see in SERVQUAL a link to the Total Quality Management (TQM) movement that gained popularity in Western economies as a response to Japanese competition grabbing market share across a wide range of product categories in the 1970 s and 1980s. The language of Quality dominated the management discourse at that time: Kaizen, Quality Circles, Just-in-Time and Lean (Womack \& Jones 2005). Declaring victory in the battle to improve product quality, consultants and academics exported their Quality programmes and management models to the service sector. Levitt (1976) argues that service should be "industrialized" (now often referred to as "productization") so that firms could realise the increased productivity seen in the goods sector. In addition to increased productivity, Reichheld and Sasser (1990) claim that adapting the "zero-defect" philosophy of product quality into service marketing would reduce customer defection and that even small reductions in defection produce disproportionate profit improvements. Other scholars suggest that the mechanism by which quality improved business results was through customer satisfaction (Anderson et al. 1994). In this model, service quality creates favourable purchasing intentions, willingness to pay more and recommendation. The link between customer satisfaction and favourable business outcomes is well established (Anderson et al. 1997), and generates great interest in measuring customer satisfaction and one of its key consequences, Net Promoter Score (Reichheld 2006). So strongly held is the view linking satisfaction, recommendation and business outcomes, that Reichheld (1996) claims that Net Promoter Score is the sole metric required to understand the effectiveness of your business from the customers' perspective. This view has been contested vigorously by researchers trying to replicate his research (Keiningham et al. 2007), yet anecdotally the authors observe that many firms request its measure from their Market Researchers. 
Service quality is originally conceptualised as a gap between expectations and the consumer's overall assessment of the service encounter (Parasuraman et al. 1988). This concept led to the popular management adage of needing to "delight" customers by always exceeding their expectations. Service Quality's most popular measure is SERVQUAL, a 22-item scale whose dimensions are: reliability, assurance, tangibility, empathy and responsiveness. When implementing the measure, researchers focus on a particular service episode and ask customers to assess the dimensions versus their prior expectations using a five point Likert scale (Morrison Coulthard 2004).

SERVQUAL has been challenged conceptually, methodologically and with respect to the validity of its dimensions. It is not the purpose of this article to review the numerous discussions on this measure, rather to draw upon that literature to assert that it is not built for today's experience focus. We suggest the following to market researchers as to how they might conceive an appropriate measure of experience quality:

(1) Scholars contest the assumption that customers assess service or experience against expectations (Cronin Jr. \& Taylor 1992). Research subsequent to Parasuraman et al. (1988) has failed to validate SERVQUAL's dimensions (Buttle 1996), thus questioning its generalisability. Experience reflects customers' overall assessment of value rather than in relation to expectations, highlighting the importance of these perceptual attributes. These attributes reflect customers' higher order objectives leading to purchasing behaviour better than technical aspects of service do, the latter subject to frequent changes due to technology and competition. Therefore perceptual attributes are more stable as the focus of evaluation of experience (Parasuraman et al. 2005).

(2) SERVQUAL focuses largely upon customers' assessment of the service process and human interactions (Mangold \& Babakus 1991; Cronin Jr. \& Taylor 1992; Richard \& Allaway 1993). The post-product, post-service perspective of marketing concentrates on customers' value-in-use: the extent to which customers have accomplished higher-order goals which represent a mix of utilitarian and emotional factors (Chitturi et al. 2008). Individual components of a service encounter may be assessed as "good quality" but that does not automatically mean that the overall experience is judged high quality, nor does measuring the components of service quality ensure that customers achieve their desired outcomes. The authors believe that SERVQUAL reflects the Quality Management origins of service quality, a manufacturing-like atomisation of complex service systems and subsequent optimisation of each component; it is highly contestable if this corresponds with how customers assess their overall experiences. Lemke et al. (2010) describe this argument as a debate between those who believe in the embedded value of a service offer versus those who believe that value is created by customers in use: cocreation.

(3) SERVQUAL's dimensions are too limited (Sureshchandar et al. 2002) to capture customer experience fully and marketing scholars suggest a broader and holistic 
conceptualisation, and therefore measure, of experience (Verhoef et al. 2009). Gentile et al. (2007, p.397) suggest "customer experience ...is strictly personal and implies the customer's involvement at different levels (rational, emotional, sensorial, physical, and spiritual)". Whilst such wide reaching conceptualisations are consistent with experience, they may be too broad to defy practical measurement and we risk that customer experience develops into the theory of everything. The existing experience research considers specific, normally high involvement, contexts given its personal and contextual nature (Sharma \& Patterson 2000; Chandon et al. 2005). This intuitively appealing approach to experience makes it difficult to create a universal measure similar to SERVQUAL, customer satisfaction or Net Promoter Score. As most of the academic publication to date is of a conceptual nature, scholars have not addressed the issue of generalisability fully. Responding to this challenge, Lemke et al. (2010) develop a generalised conceptual framework for customer experience from a cross-industry study of 40 individuals using Repertory Grid analysis. They find that experience is generated from three types of encounter: (1) communication, (2) service delivery and (3) usage. Service delivery is assessed on the basis of product, service and experience quality. The three encounters are moderated by the context of the experience; that is, involvement, complexity, relationships and the hedonic nature of the experience. They acknowledge that this study is experimental and that larger, content specific research is needed to validate the dimensions of their framework against the outcomes they propose: commitment, purchase, repeat purchase and word-of-mouth.

(4) Customers take a longitudinal perspective when assessing their experiences and will believe that they have had experience with a company even before they have bought something; this arises from advertising, promotion and word-of-mouth. Therefore, Market Researchers need to measure customer experience before and after the service encounter(s) and account for both direct and indirect contacts and peer influences (Berry et al. 2002; Payne et al. 2008). This generates practical challenges for market researchers. The longer the time frame used, the harder it is to distinguish experience from overall brand perception. Too short a time perspective, and the researcher risks assessing experience in an atomistic fashion.

(5) Experience is likely to arise across channels, the cumulative effect of numerous encounters, rather than being driven by a single episode. We do not understand how consumers synthesise these multi channel encounters into an overall assessment of experience, but it is likely not to be a pure addition of individual service episodes (Sharma \& Patterson 2000; Chandon et al. 2005).

(6) Experience research should enable more direct, empirically validated effects upon customer behaviour to improve accountability. Even strong advocates of the virtuous cycle between service quality, customer satisfaction and customer behaviour, admit that this chain is difficult to make operational (Sureshchandar et al. 2002) and researchable (Zeithaml et al. 1996). A more direct and quantifiable relationship is empirically evident between customer satisfaction and outcomes. Satisfaction builds market share profitably, thus improving shareholder value (Anderson et al. 1994; Anderson et al. 2004; Fornell et al. 2006), improves cash flow whilst reducing risk (Gruca \& Rego 2005), improves customers' commitment, 
deepens customers' relationship with the firm (Gustafsson et al. 2005) and enhances customers' propensity to pay a premium (Homburg et al. 2005). Service quality infers these benefits by suggesting the link between quality and satisfaction. Experience measures should be linked directly to exogenous variables that include "hard" behavioural outcomes close to profitability, such as repurchase.

This academic discussion so far has generated characteristics of the experience concept that can guide fieldwork: continuing to measure service quality is likely necessary for most firms, but not sufficient. Market Researchers need to develop an appropriate measure for the concept of customer experience that:

1. Is based upon an overall cognitive and emotional assessment of value from the customers' point-of-view rather than evaluated against benchmarks or expectations.

2. Captures the value-in-use of the organisation's offer, not just the attributes of product and service delivery

3. Assesses, as much as possible, emotional responses as well as the functional delivery of the organisation's promise

4. Determines a reasonable focal time period, sufficiently pre and post the service delivery, to allow the customer to assess the experience over time and across channels.

5. Is validated against behavioural measures as well as attitudinal ones.

The rest of this article illustrates how the authors executed these principles in the context of UK mortgage services.

\section{Developing a Measure of Customer Experience}

The authors worked with a major UK bank interested in understanding how to differentiate its household mortgage offer. The UK mortgage market is characterised by revolving two or three-year contracts such that consumers face repurchase decisions frequently over the lifetime of their mortgages thus generating high levels of customer defection and frequent price-based promotions. We developed a measure for Customer Experience Quality (EXQ) to identify the dimensions, and their attributes, that explain its most important marketing outcomes: loyalty (defined as repurchase of the mortgage), word-of-mouth recommendation (Samson 2006) and satisfaction. Those marketing outcomes represent the authors' synthesis of the academic literature on customer experience and relevant scale development. The methodology followed Churchill's (1979) widely cited scale development paradigm (Terblanceh \& Boshoff 2008) and other relevant scale-developing studies (e.g. Walsh \& Beatty 2007). It was developed in four stages: (1) scale generation, (2) initial purification, (3) refinement and (4) validation against the most important marketing outcomes. These stages are described briefly below. It is not the authors' intention to focus this article on scale development methods, rather this is presented as an example to market researchers of how they might address the challenge of moving to a post-service measure of customer experience (Appendix 1). 


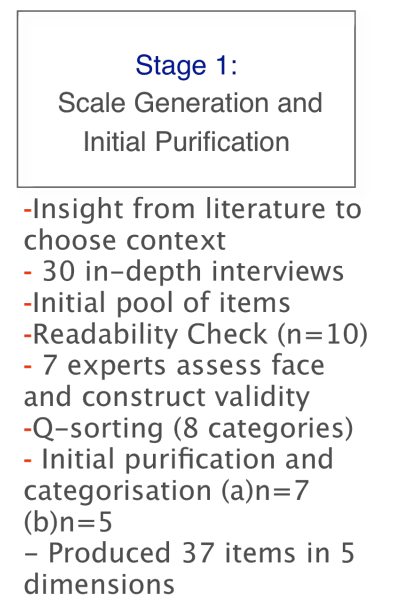

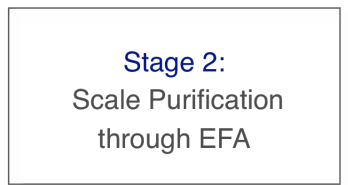

- Collect responses from representative sample $(n=75)$

- Exploratory factor analysis (on 5dimensional model) - Assess content validity, scale reliability and validity

- Develop purified scale with 19 items in four dimensions for next stage

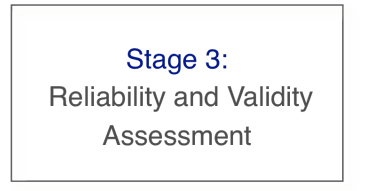

-Additional representative sample $(n=218)$

- Confirmatory factor

analysis on 4-dimensional model

- Assess factor structure and dimensionality of scale

- Assess model fit

-Assess scale and

construct reliability and

discriminant validity

- Final EXQ scale of 19 items in four dimensions

\section{Stage 4:}

Conceptual Framework and SEM connection to outcomes

- Test salience of EXQ scale in explaining variances and predictive ability to important customer experience outcomes: customer satisfaction, loyalty, and word-of-mouth intentions
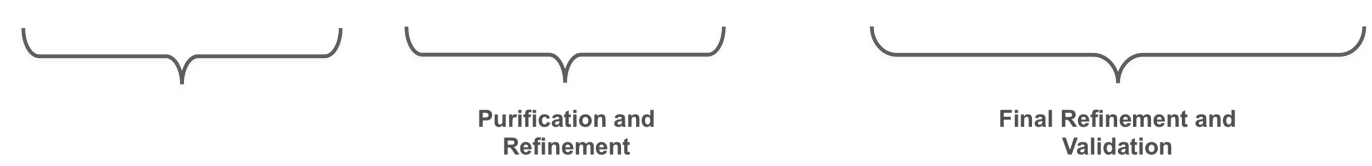

Stage 1 - Scale generation articulates the meaning and domain of service experience based on insights from the literature and a comprehensive qualitative study. It results in a preliminary scale containing 37 items that represent five dimensions.

Stage 2 - Initial purification assesses the scale with a representative sample of the bank's repeat mortgage purchasers (75 qualified responses). Using exploratory factor analysis, the scale is purified to 19 items that represent four customer experience dimensions.

Stage 3 - Refinement via confirmatory factor analysis (CFA) validates the purified scale based on a representative sample (218 qualified responses), which confirms the scale's reliability and validity.

Stage 4 - Validation is achieved by assessing the extent to which customer experience, and its dimensions, explain consumers' overall satisfaction perceptions, repeat purchase and word-of-mouth.

\section{Stage 1: Scale Generation}

Stage 1 explores the perceptual attributes of experience through in-depth interviews using soft laddering (Grunert \& Grunert 1995), a technique where respondents are restricted as little as possible in their natural flow of speech. This is an accepted method for assessing consumers' cognitive structures and underlying purchasing (Reynolds \& Gutman 1988). 
We achieved data saturation (Glaser \& Strauss 1967) after conducting individual indepth interviews with 30 mortgage customers from the UK over a four week period: each interview lasted between 30 to 60 minutes. We used a random sample of the Bank's customers who had purchased one or more mortgages in the previous six months, split between first time buyers and repeat buyers.

The interviews were transcribed, coded and analysed following a grounded approach (Strauss \& Corbin 1998); 58 customer experience items were generated. To maximise the content and face validity of the items generated, a panel of expert judges reviewed the retained item pool (Dagger et al. 2007) and performed three tasks: (1) assessed the similarity of items, the clarity of phrasing and the terminology used in the scale, (2) rated each item with respect to its relevance to the item description and (3) suggested dimensions and sub-dimensions that evolved from the research model and items. Five dimensions representing 37 items resulted from this stage.

\section{Stage 2: Scale Purification through Exploratory Factor Analysis (EFA)}

The scale was purified through EFA. Data were collected through an online questionnaire accessible through a link sent by the bank to a sample of customers who had purchased more than one mortgage from the Bank and the most recent mortgage within the previous six months, resulting in a sample of 75 repeat purchasers.

Exploratory factor analysis summarises the data into a minimum number of factors for prediction purposes. The resulting purified scale comprises four primary dimensions with 19 corresponding items which, in conjunction with the expert panel, were labelled as follows to make the acronym POMP:

1. Product experience - Customers' perception of having choices and the ability to compare offers. Interviewees often referred to the need to compare offers, even if they were from the same provider and differed merely in length of the mortgage, because it "gave them the feeling of having a choice", and without a choice they were unlikely to accept the offer "no matter how good it was".

2. Outcome focus - is associated with reducing customers' transaction costs, such as seeking out and qualifying new providers: "We just wanted to get the mortgage as soon as possible." Also, once a relationship is established, these goal-oriented past experiences (Roy et al. 1996) build a habit despite the awareness of competitors' offers: "I know there are better offers, but why should I bother; here I know what I will get and it's straightforward."

3. Moments-of-truth - This dimension is characterised by that which is commonly knows as moments-of-truth, emphasising the importance of service recovery (Tax \& Brown 1998) and flexibility (Liljander \& Strandvik 1997) when faced with unforeseen complications. This dimension also incorporates evaluations of Bank employees' interpersonal skills connected to these moments-of-truth: "I was really upset about 
what happened, but the way they [the Bank] dealt with me, gave me the confidence that I had made the right decision in staying with them."

4. Peace-of-mind - This dimension includes statements associated strongly with the emotional aspects of service and is based upon the perceived expertise of the service provider and the guidance provided throughout the process (Bendapudi \& Berry 1997). These attributes put customers "at ease" and increase "confidence in the provider". In this research, customers link peace-of-mind with their relationship to the Bank and express a preference for being dealt with as a valued customer rather than in a "purely transactional way."

It is worth noting that the cost of the mortgage and brand of the supplier, which featured in the qualitative stage as motivators of consumer behaviour, proved insignificant statistically when assessed quantitatively. In this study, the costs of searching, applying, securing and paying for the mortgage are not significantly related to the quality of service experience. The costs associated with searching for a mortgage, however, are captured by the dimension outcome focus.

\section{Stages 3 \& 4: Reliability and Validity Assessment through Confirmatory Factor Analysis}

To perform the analysis, 218 qualified responses were collected through an online questionnaire accessible through a link sent by the Bank to a random sample of customers who had repurchased within the previous six months. The exploratory and confirmatory analysis samples are analogous do not differ significantly in terms of age, gender and educational background (see Appendix 3).

Existing scale development studies generated measures of the exogenous variables: customer satisfaction, loyalty and word-of-mouth intentions. The outcome is a scale measure of customer experience (EXQ) illustrated in Figure 1. A full definition of each of the attributes identified in the left hand side boxes is provided in Appendix 2. The authors are happy to share further data of method, questionnaire, results and attendant validity testing with any interested readers. 


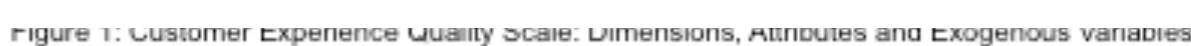

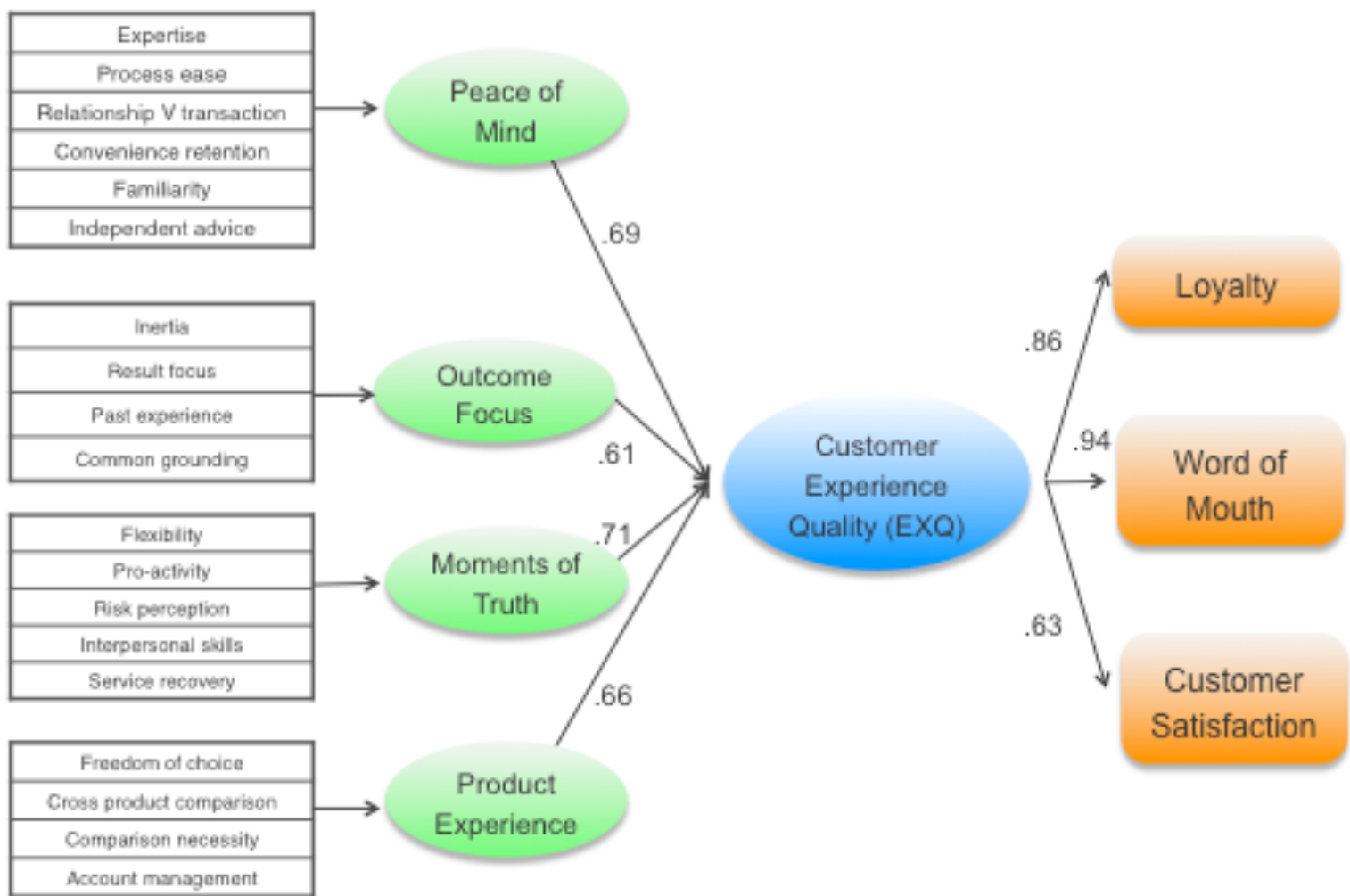

The scale developed demonstrates high validity and reliability in explaining the relationship between customer experience and the selected outcomes. The squared multiple correlations are as follows: for loyalty - 86\%, customer satisfaction - $63 \%$ and for positive word-of-mouth intention - 94\%.

We compare the explanatory power of EXQ with customer satisfaction and our findings (Table 1) demonstrate stronger relationships between service experience and loyalty, as defined in this study, than between customer satisfaction and loyalty. Compared with the relationship between customer satisfaction and word-of-mouth, we also establish a more direct link between service experience and word-of-mouth. Therefore, whilst there is a body of literature offering customer satisfaction as a mediator between service quality and loyalty and word-of-mouth (Seiders et al. 2005), customer experience could be an even better predictor of loyalty and word-ofmouth.

Table 1

Explanatory power of experience and satisfaction

$\begin{array}{llll} & \text { Customer satisfaction } & \text { Loyalty } & \text { Word-of-mouth } \\ \text { Experience quality } & 0.63 & 0.86 & 0.94 \\ \text { Customer satisfaction } & - & 0.65 & 0.87\end{array}$

We describe the importance of the individual dimensions of customer experience in relation to these important marketing outcomes (Table 2):

$\begin{array}{lccc}\text { Table } 2 & \text { Standard path estimates } & & \\ \text { Dimension } & \text { Customer satisfaction } & \text { Loyalty } & \text { Word-of-mouth } \\ \text { Peace-of-mind } & 0.90 & 0.72 & 0.40 \\ \text { Outcome focus } & 0.09 & 0.20 & 0.20 \\ \text { Moments-of-truth } & 0.04 & 0.13 & 0.09 \\ \text { Product experience } & 0.10 & 0.09 & 0.04\end{array}$


The dimension peace-of-mind, strongly associated with the emotional aspects of the service evaluation, has the strongest correlation of all EXQ dimensions, with the outcome variables customer satisfaction (0.90), loyalty (0.72) and word-of-mouth $(0.40)$. This dimension is highly relevant because of its close link to direct interactions and the resulting customer experiences with the service company. Based on their own first-hand experiences with the service company, customers have the ability to evaluate not only the companies' offers, but also the experiences connected with these interactions.

Moments-of-truth display a positive impact on loyalty $(0.13)$ and a medium association with word-of-mouth (0.09). However, the dimension has no significant association with customer satisfaction (0.04). The literature states that effective service recovery can be more important than initial service experiences in influencing customer satisfaction (Bitner et al. 1997). Our findings do support this, perhaps due to the significantly higher influence of initial service attributes within the dimension peace-of-mind (0.90) on the overall customer satisfaction.

Outcome focus, reflecting the importance of goal-oriented experiences, also has an important effect on loyalty $(0.20)$ and word-of-mouth $(0.20)$, although to a lesser extent than peace-of-mind. Outcome focus demonstrates a medium association with customer satisfaction (0.09). These correlations suggest the importance of past experiences with the service company in forming positive behavioural intentions and, therefore, our construct has a temporal aspect as suggested in the literature.

The dimension product experience displays the second highest association of all constructs with customer satisfaction (0.10), a medium association to loyalty $(0.09)$, but only a low effect on word-of-mouth (0.04). The relatively weak association with word-of-mouth suggests that this dimension is important for the interactions and future relationship with the service company. It seems counter-intuitive that customers satisfied with the product's performance do display this satisfaction by recommending the firm to potential customers. We believe that this could be a function of the context (mortgages) and one might have a different outcome in the context of high involvement categories such as cars, personal computers, mobile phones and travel where we posit that consumers share their experiences more readily.

Our study discovers that the four POMP dimensions of customer experience explain most of the Bank's loyalty, word-of-mouth and customer satisfaction. The findings indicate that customers evaluate the customer experience at an overall level, a dimensional level and at attribute level and that each level drives perception on the level above.

These findings support conceptual papers that suggest the customer experience is broadly based (Schembri 2006; Berry et al. 2006), yet not as broad as suggested by some (Verhoef et al. 2009; Gentile et al. 2007; Meyer \& Schwager 2007). Dimensions arising from the literature and even from the qualitative stage, such as social interactions (Bagozzi 2000), brand (Brodie 2006) and price (Baker et al. 2002) are not significant. One possible explanation for this counter-intuitive finding is that 
the sample comprises repeat customers. Nonetheless, the results suggest that researchers should not over-compensate for the limitations of the traditional conceptualisation of product or service quality. It is likely that practicing researchers will need to model customer experience for their unique context; current generic conceptualisations of experience may be too broad to be actionable and relevant in any one context.

\section{Conclusions}

The rapid evolution of marketing focus from product to service to experience challenges market researchers to take a strategic role in their organisations or when engaged with their clients. That which researchers traditionally measure fails to capture fully the value upon which organisations need to compete - customer experience. The managerial focus on customer experience is validated by the findings, which link customer experience to these important marketing outcomes.

Experience is far broader and less bordered than the concept of product or service quality that it replaces; hence its measure is far more complex. However, experience is not all encompassing and it is incumbent on the researcher to uncover what attributes and dimensions are in or out, and which ones matter most. In so doing, marketing investments can be directed more effectively to maximise drivers of financial performance, namely loyalty, satisfaction and share-of-wallet.

Scales, such as EXQ described in this article, can help market researchers. They identify attributes of the customers' experience most strongly associated with the marketing outcomes organisations are trying to achieve as a focus for management attention and investment. As illustrated in our development of a scale for a mortgage provider, key attributes of customer experience are not likely captured in current market research assessments of service quality or customer satisfaction. Scales also allow tracking both of customer experience and its key attributes over time and can act as an important marketing metric.

Managers should consider customer experience as an important strategic objective. In the limited context that we present, EXQ explains word-of-mouth and loyalty better than customer satisfaction. Obviously these results need to be confirmed in other contexts and longitudinally before market researchers consider replacing the universally understood metric of customer satisfaction. Based on the attributes and dimensions of service experience, we believe that our findings are of particular relevance to other high involvement, high contact professional services. 


\section{References}

Achrol, R. \& Kotler, P., 1999. Marketing in the Network Economy. Journal of Marketing, 63, 146-163.

Anderson, E., Fornell, C. \& Agarwal, S., 2004. Customer Satisfaction and Shareholder Value. Journal of Marketing, 68, 172-185.

Anderson, E., Fornell, C. \& Lehmann, D., 1994. Customer Satisfaction, Market Share and Profitability: Findings from Sweden. Journal of Marketing, 58, 53-66.

Anderson, E., Fornell, C. \& Rust, R., 1997. Customer Satisfaction, Productivity, and Profitability: Differences between Goods and Services. Marketing Science, 16(2), 129-145.

Arnould, E. \& Price, L., 1993. River Magic: Extraordinary Experience and the Extended Service Encounter. Journal of Consumer Research, 20(1), 24-45.

Bagozzi, R., 2000. On the Concept of Intentional Social Action in Consumer Behavior. Journal of Consumer Research, 27(3), 388-396.

Baker, J. et al., 2002. The Influence of Multiple Store Environment Cues on Perceived Merchandise Value and Patronage Intentions. Journal of Marketing, 66(2), 120-141.

Bendapudi, N. \& Berry, L., 1997. Customer's Motivations for Maintaining Relationships with Service Providers. Journal of Retailing, 73(1), 15-37.

Berry, L., Carbone, L. \& Haeckel, S., 2002. Managing the Total Customer Experience. Sloan Management Review, 43(3), 85-89.

Berry, L., Wall, E. \& Carbone, L., 2006. Service Clues and Customer Assessment of the Service Experience: Lesson from Marketing. The Academy of Management Perspectives, 20(2), 43.

Bitner, M.J. et al., 1997. Customer Contributions and Roles in Service Delivery. International Journal of Service Industry Management, 8(3), 193.

Brodie, R., 2006. The Service Brand and the Service-Dominant Logic: Missing Fundamental Premise or the Need for Stronger Theory? Marketing Theory, 6(3), 363-379.

Buttle, F., 1996. SERVQUAL: Review, Critique, Research Agenda. European Journal of Marketing, 30(1), 8.

Chandon, P., Morwitz, V. \& Reinartz, W., 2005. Do Intentions Really Predict Behavior? Self-Generated Validity Effects in Survey Research. Journal of Marketing, 69(2), 114. 


\section{Customer Experience: Are we Measuring the Right Things?}

Chitturi, R., Raghunathan, R. \& Mahajan, V., 2008. Delight by Design: The Role of Hedonic Versus Utilitarian Benefits. Journal of Marketing, 72(3), 48-63.

Christopher, M., 1996. From Brand Value to Customer Value. Journal of Marketing Practice, 2(1), 55-66.

Churchill Jr., G., 1979. A Paradigm for Developing Better Measures of Marketing Constructs. Journal of Marketing Research (JMR), 16(1), 64-73.

Coviello, N. et al., 2002. How Firms Relate to Their Markets: An Empirical Examination of Contemporary Marketing Practices. Journal of Marketing, 66(3), 33-46.

Cronin Jr., J. \& Taylor, S., 1992. Measuring Service Quality: A Reexamination and Extension. Journal of Marketing, 56(3), 55-68.

Dagger, T., Sweeney, J. \& Johnson, L., 2007. A Hierarchical Model of Health Service Quality: Scale Development and Investigation of an Integrated Model. Journal of Service Research, 10(2), 123-142.

Fornell, C. et al., 2006. Customer Satisfaction and Stock Prices: High Returns, Low Risk. Journal of Marketing, 70(1), 3-14.

Gambetti, R. \& Graffigna, G., 2010. The concept of engagement. International Journal of Market Research, 52(6), 801-826.

Gentile, C., Spiller, N. \& Noci, G., 2007. How to Sustain the Customer Experience:An Overview of Experience Components that Co-create Value With the Customer. European Management Journal, 25(5), 395-410.

Gilmore, J. \& Pine II, B., 1997. Beyond Goods and Services. Strategy \& Leadership, 25(3), 10.

Gilmore, J. \& Pine II, B., 2002. Customer Experience Places: The New Offering Frontier. Strategy \& Leadership, 30(4), 4.

Glaser, B. \& Strauss, A., 1967. The Discovery of Grounded Theory, Chicago: Aldine.

Gordon, W., 2006. Out with the New, in with the Old. International Journal of Market Research, 48(1), 7-25.

Gronroos, C., 1994. Quo Vadis, Marketing? Toward a Relationship Marketing Paradigm. Journal of Marketing Management, 10(5), 347-360.

Gruca, T. \& Rego, L., 2005. Customer Satisfaction, Cash Flow, and Shareholder Value. Journal of Marketing, 69(3), 115-130.

Grunert, K. \& Grunert, S., 1995. Measuring Subjective Meaning Structures by the Laddering Method: Theoretical Considerations and Methodological Problems. International Journal of Research in Marketing, 12(3), 209-225. 


\section{Customer Experience: Are we Measuring the Right Things?}

Gustafsson, A., Johnson, M. \& Roos, I., 2005. The Effects of Customer Satisfaction, Relationship Commitment Dimensions, and Triggers on Customer Retention. Journal of Marketing, 69(4), 210-218.

Hoffman, D. \& Novak, T., 1996. Marketing in Hypermedia Computer-Mediated Environments: Conceptual Foundations. Journal of Marketing, 60(3), 50-68.

Homburg, C., Koschate, N. \& Hoyer, W., 2005. Do Satisfied Customers Really Pay More? A Study of the Relationship between Customer Satisfaction and Willingness to Pay. Journal of Marketing, 69(2), 84-95.

Keiningham, T. et al., 2007. A Longitudinal Examination of Net Promoter and Firm Revenue Growth. Journal of Marketing, 71, 39-51.

Klaus, P. \& Maklan, S., 2007. The Role of Brands in a Service-Dominated World. Journal of Brand Management, 15(2), 115.

Lemke, F., Clark, M. \& Wilson, H., 2010. Customer Experience Quality: An Exploration in Business and Consumer Contexts Using Repetory Grid Technique. Journal of the Academy of Marketing Science.

Levitt, T., 1976. The Industrialization of Service. Harvard Business Review, 54(5), 63-74.

Liljander, V. \& Strandvik, T., 1997. Emotions in Service Satisfaction. International Journal of Service Industry Management, 8(2), 148-169.

Macdonald, E., Martinez, V. \& WIlson, H., 2009. Towards the Assessment of the Value-InUse of Product-Service Systems: A Review. In Performance Assocation Conference. Dunedin, New Zealand.

Maklan, S. \& Knox, S., 2009. Dynamic Capabilities: The Missing Link in CRM Investments. European Journal of Marketing, 43(11/12), 1392.

Mangold, W. \& Babakus, E., 1991. Service Quality: The Front-Stage vs. the Back-Stage Perspective. The Journal of Services Marketing, 5(4), 59.

Meyer, C. \& Schwager, A., 2007. Understanding Customer Experience. Harvard Business Review, 85(2), 116.

Morrison Coulthard, L., 2004. Measuring Service Quality. International Journal of Market Research, 46(4), 479-497.

Parasuraman, A., Zeithaml, V. \& Berry, L., 1988. Servqual: A Multiple-Item Scale For Measuring Consumer Perceptions of Service Quality. Journal of Retailing, 64(1), 1240.

Parasuraman, A., Zeithaml, V.A. \& Malhotra, A., 2005. E-S-QUAL: A Multiple-Item Scale for Assessing Electronic Service Quality. Journal of Service Research, 7(3), 213-233.

Payne, A., Storbacka, K. \& Frow, P., 2008. Managing the Co-Creation of Value. Journal of 
the Academy of Marketing Science, 36(1), 83-96.

Payne, A. \& Frow, P., 2005. A Strategic Framework for Customer Relationship Management. Journal of Marketing, 69(4), 167-176.

Peppers, D. \& Rogers, M., 1994. The One-to-One Future, London: Piatikus.

Pine II, J. \& Gilmore, J., 2004. Experience is Marketing. Brand Strategy, (187), 50-51.

Rayport, J. \& Sviokla, J., 1994. Managing in the Marketspace. Harvard Business Review, 72(6), 141-150.

Reichheld, F., 1996. The Loyalty Effect, Boston, Mass.: Harvard Business School Press.

Reichheld, F., 2006. The Microeconomics of Customer Relationships. MIT Sloan Management Review, 47(2), 73-78.

Reichheld, F. \& Sasser, W., 1990. Zero Defects: Quality Comes to Service. Harvard Business Review, 68(5), 105-111.

Reynolds, T. \& Gutman, J., 1988. Laddering Theory Method, Analysis, And Interpretation. Journal of Advertising Research, 28(1), 11.

Richard, M. \& Allaway, A., 1993. Service Quality Attributes and Choice Behavior. The Journal of Services Marketing, 7(1), 59.

Roy, R., Chintagunta, P. \& Haldar, S., 1996. A Framework for Investigating Habits, "The Hand of the Past," and Heterogeneity in Dynamic Brand Choice. Marketing Science, 15(3), 280-299.

Samson, A., 2006. Understanding the Buzz that Matters: Negative vs Positive Word of Mouth. International Journal of Market Research, 48(6), 647-657.

Schembri, S., 2006. Rationalizing Service Logic, or Understanding Services as Experience? Marketing Theory, 6(3), 381.

Schouten, J. \& McAlexander, J., 1995. Subcultures of Consumption: An Ethnography of the New Bikers. Journal of Consumer Research, 22(1), 43-61.

Seiders, K. et al., 2005. Do Satisfied Customers Buy More? Examining Moderating Influences in a Retailing Context. Journal of Marketing, 69, 26-43.

Sharma, N. \& Patterson, P., 2000. Switching Costs, Alternative Attractiveness and Experience as Moderators of Rrelationship Commitment in Professional, Consumer Services. International Journal of Service Industry Management, 11(5), 470.

Sheth, J., Sisodia, R. \& Sharma, A., 2000. The Antecedents and Consequences of CustomerCentric Marketing. Journal of the Academy of Marketing Science, 28(1), 55-66.

Strauss, A. \& Corbin, J., 1998. Basics of Qualitative Research: Techniques and Procedures 
for Developing Grounded Theory Second Edition., Thousand Oaks: Sage Publications, Inc.

Sureshchandar, G., Rajendran, C. \& Anantharaman, R., 2002. The Relationship Between Management's Perception of Total Quality Service and Customer Perceptions of Service Quality. Total Quality Management, 13(1), 69-88.

Tax, S. \& Brown, S., 1998. Recovering and Learning from Service Failure. Sloan Management Review, 40(1), 75-88.

Terblanceh, N. \& Boshoff, C., 2008. Improved Scale Development in Marketing. International Journal of Market Research, 50(1), 105-119.

Vargo, S. \& Lusch, R., 2004. Evolving to a New Dominant Logic for Marketing. Journal of Marketing, 68(1), 1-17.

Verhoef, P. et al., 2009. Customer Experience Creation: Determinants, Dynamics and Management Strategies. Journal of Retailing, 85(1), 31-41.

Walsh, G. \& Beatty, S., 2007. Customer-Based Corporate Reputation of a Service Firm: Scale Development and Validation. Journal of the Academy of Marketing Science, 35(1), 127-143.

Weiber, R. \& Kollman, T., 1998. Competitive Advantages in Virtual Markets-Perspectives of "Information-Based Marketing" in Cyberspace. European Journal of Marketing, 32(7), 603-615.

Wilkinson, A., Dainty, A. \& Neely, A., 2009. Changing Times and Changing Timescales: The Servitization of Manufacturing. International Journal of Operations \& Production Management, 29(5), 7-7.

Womack, J. \& Jones, D., 2005. Lean Consumption. Harvard Business Review, 83(3), 59-68.

Zeithaml, V., Berry, L. \& Parasuraman, A., 1996. The Behavioral Consequneces of Service Quality. Journal of Marketing, 60(2), 31-46. 


\section{Appendix 1: Research Process Scale Development for UK Bank}

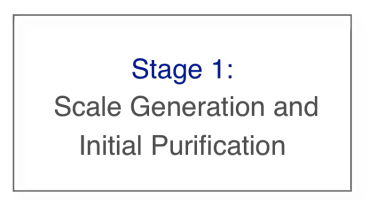

-Insight from literature to choose context

- 30 in-depth interviews

-Initial pool of items

-Readability Check $(n=10)$

- 7 experts assess face and construct validity

-Q-sorting (8 categories)

- Initial purification and

categorisation (a) $n=7$

(b) $n=5$

- Produced 37 items in 5

dimensions

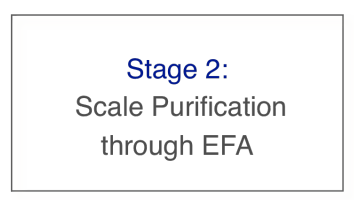

- Collect responses from representative sample $(\mathrm{n}=75)$

- Exploratory factor analysis (on 5-

dimensional model)

- Assess content validity, scale reliability and validity

- Develop purified scale with 19 items in four dimensions for next stage

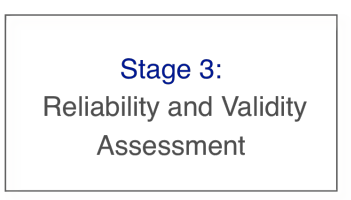

-Additional representative sample $(n=218)$

- Confirmatory factor

analysis on 4-dimensional

model

- Assess factor structure

and dimensionality of

scale

- Assess model fit

-Assess scale and

construct reliability and

discriminant validity

- Final EXQ scale of 19

items in four dimensions

\begin{tabular}{l} 
Stage 4: \\
$\begin{array}{c}\text { Conceptual Framework and } \\
\text { SEM connection to outcomes }\end{array}$ \\
\hline - Test salience of EXQ \\
scale in explaining \\
variances and predictive \\
ability to important \\
customer experience \\
outcomes: customer \\
satisfaction, loyalty, and \\
word-of-mouth intentions
\end{tabular}

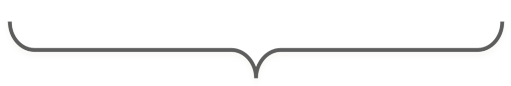

Final Refinement and Validation 
Customer Experience: Are we Measuring the Right Things?

\section{Appendix 2: Comparison of Samples}

The samples are analogous and a $\chi^{2}$ exposed that the samples do not differ significantly in terms of age, gender and educational background.

Variable

Age in Years

$18-25$

26-35

36-45

46-55

$56-64$

$65+$

Sex

Male

Female

Level of Education

High School or less

Some College

College Graduate

Graduate School
Exploratory Study

Percentage

2.20

36.00

29.30

20.90

11.60

$\mathrm{NA}^{\mathrm{a}}$

64.00

46.00

31.90

47.50

12.80

7.8
Confirmatory Study

Percentage

3.10

34.40

28.10

20.00

10.60

3.80

60.20

39.80

36.00

50.30

12.40

1.3 


\section{Appendix 3: Definitions of Experience Quality Attributes}

Attributes and their definitions were generated in stage one - scale generation and initial purification (See appendix 1). Respondents rated their customer experiences on each scale item using a seven-point scale. The items below are grouped by dimension for expositional convenience and appeared in random order on the questionnaire.

\begin{tabular}{|c|c|c|}
\hline Dimension & Attribute & Definition \\
\hline \multirow[t]{6}{*}{$\begin{array}{l}\text { Peace-of- } \\
\text { Mind }\end{array}$} & Expertise & $\begin{array}{l}\text { I am confident in their expertise; they know what } \\
\text { they are doing. }\end{array}$ \\
\hline & Process Ease & $\begin{array}{l}\text { The whole process was so easy; they took care } \\
\text { of everything. }\end{array}$ \\
\hline & $\begin{array}{l}\text { Relationship versus } \\
\text { Transaction }\end{array}$ & $\begin{array}{l}\text { It is not just about the now; this company is } \\
\text { looking after me. }\end{array}$ \\
\hline & $\begin{array}{l}\text { Convenience } \\
\text { Retention }\end{array}$ & $\begin{array}{l}\text { I am already a customer; they know me and take } \\
\text { good care of me, so why should I go elsewhere? }\end{array}$ \\
\hline & Familiarity & $\begin{array}{l}\text { I have dealt with them before, so getting a } \\
\text { mortgage was really easy. }\end{array}$ \\
\hline & Independent Advice & $\begin{array}{l}\text { I choose them because they give independent } \\
\text { advice. }\end{array}$ \\
\hline \multirow[t]{4}{*}{$\begin{array}{l}\text { Outcome } \\
\text { Focus }\end{array}$} & Inertia & $\begin{array}{l}\text { Yes, there are other companies, but I would } \\
\text { rather stay with mine; it makes the process much } \\
\text { easier. }\end{array}$ \\
\hline & Result Focus & $\begin{array}{l}\text { It was more important to get the mortgage than } \\
\text { to shop around for a better rate. }\end{array}$ \\
\hline & Past Experience & $\begin{array}{l}\text { I stay with my company because I am not } \\
\text { confident about using an alternative provider. }\end{array}$ \\
\hline & Common Grounding & $\begin{array}{l}\text { It was important that the advisor had a mortgage } \\
\text { too; he/she knew what I was going through. }\end{array}$ \\
\hline \multirow[t]{5}{*}{$\begin{array}{l}\text { Moments- } \\
\text { of-Truth }\end{array}$} & Flexibility & $\begin{array}{l}\text { It was important that the company was flexible in } \\
\text { dealing with me and looking out for my needs. }\end{array}$ \\
\hline & Pro-activity & $\begin{array}{l}\text { It is important that they keep me up-to-date and } \\
\text { inform me about new options. }\end{array}$ \\
\hline & Risk Perception & $\begin{array}{l}\text { I want to deal with a safe company, because a } \\
\text { mortgage is a lot of money. }\end{array}$ \\
\hline & Interpersonal Skills & $\begin{array}{l}\text { It is important that the people I am dealing with } \\
\text { are good people; they listen, are polite and make } \\
\text { me feel comfortable. }\end{array}$ \\
\hline & Service Recovery & $\begin{array}{l}\text { The way they deal(t) with me when things go } \\
\text { (went) wrong will decide if I stay with them. }\end{array}$ \\
\hline Product & Freedom of Choice & I want to choose between different options to \\
\hline
\end{tabular}


Customer Experience: Are we Measuring the Right Things?

\begin{tabular}{|l|l|l|}
\hline Experience & Freedom of Choice & make certain I get the best offer. \\
\cline { 2 - 3 } & $\begin{array}{l}\text { Cross Product } \\
\text { Comparison }\end{array}$ & $\begin{array}{l}\text { It is important to me to receive mortgage offers } \\
\text { from different companies. }\end{array}$ \\
\cline { 2 - 3 } $\begin{array}{l}\text { Comparison } \\
\text { Necessity }\end{array}$ & $\begin{array}{l}\text { Unless I can compare different options, I will not } \\
\text { know which one is the best for me. }\end{array}$ \\
\cline { 2 - 3 } & $\begin{array}{l}\text { Account } \\
\text { Management }\end{array}$ & $\begin{array}{l}\text { It would be great if I could deal with one } \\
\text { designated contact through the entire process of } \\
\text { getting my mortgage. }\end{array}$ \\
\hline
\end{tabular}

